\title{
LIVING HADITTH WAKAF MENURUT ULAMA TRADISIONAL DAN MODERN DI GRESIK
}

\author{
Abu Azam Al Hadi \\ Universitas Islam Negeri Sunan Ampel Surabaya, Indonesia \\ E-mail: abuazam_al@yahoo.com
}

\begin{abstract}
This article focuses on the meanings of hadîth on waqf according to traditionalist and modern 'ulama in Gresik, East Java. The signification of hadîth related to religious benefaction (waqf) certainly has various aspects in terms of the social and cultural contexts of the Prophetic traditions. Hadîth on waqf has been subject of different meanings reconstruction among Muslim jurists in contemporary context. According to tradisionalist 'ulama, waqf can be meant as sadaqah jâriyah. They maintain that waqf is turning over properties which have the value of benefit to administrators of waqf who are responsible to maintain the original form of properties. Meanwhile, modern 'ulama argue that waqf is turning over the 'existing' property either eternally or temporally to be used directly and its benefit can be taken continously for the sake of common good or public interest. Waqf is sadaqah jâriyah, the reward of which flows continously. The meaning of 'existing' is that the age of submitted property is determined by its economic value, or as it is written in the statement of waqf. Different meanings of waqf according to traditionalist and modern 'ulama are influenced by their educational backgrounds.
\end{abstract}

Keywords: Living hadîth; waqf; traditionalist and modern 'ulama.

\section{Pendahuluan}

Sebagai sumber hukum Islam kedua setelah al-Qur'ân, Hadîth memerlukan upaya kontekstualisasi dalam kehidupan sehari-hari. Namun sebelum itu, hadith yang pada awalnya merupakan tradisi "lisan" yang hidup dan fleksibel kemudian menjadi tradisi "tertulis" yang beku dan kaku. Perlu ada usaha untuk mereorientasikan pemahaman makna hadîth terlebih dahulu, apalagi hadîth-ḥadîth yang berkaitan dengan persoalan hukum, politik, sosial, ekonomi, dan 
budaya yang memberikan peluang bagi kita untuk melakukan kajian dan pembaruan penafsiran dan pemaknaan terhadap hadith. Usaha tersebut mutlak dilakukan karena situasi dan pranata sosial, hukum, ekonomi, budaya, dan politik ketika hadîth-ḥadîth tersebut dibukukan sangat berbeda dengan pranata masa sekarang di mana pun umat Islam berada. Oleh karena itu, diperlukan ijtihad untuk mencapai kemungkinan tafsir-tafsir baru dengan pengembangan wilayah pranata-pranata yang ada.

Pemaknaan dengan pendekatan sosiologis terhadap suatu hadîth merupakan usaha untuk memahami hadith dari aspek tingkah laku sosial masyarakat pada saat itu. Dengan demikian, bisa dikatakan bahwa pemaknaan dengan pendekatan sosiologis terhadap hadîth adalah mencari uraian dan alasan tentang kondisi sosial masyarakat yang berhubungan dengan ketentuan-ketentuan dalam hadîth. Dengan menggunakan pendekatan sosiologis dalam memahami hadîth secara kontekstual, paling tidak hal ini dapat mengukur sejauh mana efektivitas sebuah hadîth dalam konteks hari ini, karena tentu saja memahami hadîth dengan baik juga merupakan sebagai sarana mencapai keadaan-keadaan sosial tertentu yang lebih baik.

Di samping itu secara rasional dapat dikatakan bahwa pemaknaan hadîth Nabi hakikatnya adalah memahami seluruh proses kehidupan yang berdasarkan al-Qur'ân. Jadi, hadîth sebagai follow up sistem ajaran untuk kaum Muslimin yang diwariskan oleh generasi awal Islam, bukan berarti diterima secara taken for granted, melainkan menerimanya dengan jeli, hati-hati, dan kritis sesuai dengan prinsip-prinsip dalam 'ulùm al-ḥadîth yang telah dibangun oleh muḥaddithîn (pakar hạaîth). ${ }^{1}$

Dengan pendekatan sosiologis kajian ini diharapkan dapat memeroleh pemaknaan hadîth yang kontekstual dengan cara mendeskripsikan dan menelusuri pemaknaan hadîth-ḥadîth tentang "wakaf". Di samping itu, kajian ini bertujuan untuk mengetahui relevansi pemaknaan hadîth tentang "wakaf" dalam konteks masyarakat Muslim di Gresik dan umumnya di Indonesia yang sering berbeda dalam mamahami hadîth "wakaf".

Yang dimaksud ulama tradisional di sini adalah ulama yang tidak memiliki atau bukan pemangku pondok pesantren, tetapi di tengah masyarakat dalam kesehariannya mereka selalu dipanggil kiai.

\footnotetext{
1 Abdul Mustaqim, Paradigma Integrasi-Interkoneksi dalam Memahami Hadis (Yogyakarta: Teras, 2009), 30.
} 
Umumnya mereka pernah mengenyam pendidikan diniyah pesantren. Sedangkan ulama modern adalah mereka yang memiliki dasar pendidikan diniyah dari pesantren, dan melanjutkan pendidikannya sampai tingkat perguruan tinggi, dan bukan pemangku pondok pesantren.

Ulama tradisional adalah sosok ulama yang berperan dalam segala aspek kehidupan beragama dan bernegara dengan menjunjung idealisme demi tegaknya kebenaran, keadilan, dan kemaslahatan. Di samping itu dalam pendekatan pemaknaan hadîth, cenderung tekstual dan berafiliasi pada mazhab Shâfî̀. Ulama modern adalah sosok ulama yang mempunyai worldview lebih moderat, dan dalam pendekatan pemaknaan hadîth lebih kepada pemaknaan konstektual serta tidak terpengaruh dengan satu mazhab tertentu.

\section{Pemaknaan Hadîth}

Pendekatan dan pemaknaan sosiologis sangat diperlukan dalam memahami hadîth Nabi Muhammad. Pendekatan sosiologis dalam memahami hadîth itu dimaksudkan agar pemahaman terhadap sebuah hadîth harus mengorelasikannya dengan keadaan masyarakat setempat secara umum. Kondisi masyarakat pada saat munculnya hadîth boleh jadi sangat memengaruhi munculnya suatu hadîth. ${ }^{2}$ Jadi keterkaitan antara hadîth dengan situasi dan kondisi masyarakat pada saat itu tidak dapat dipisahkan. Karena itu dalam memahami hadîth kondisi masyarakat harus dipertimbangkan agar pemaknaan tersebut tidak salah.

Pendekatan sosiologis terhadap pemaknaan suatu hadîth merupakan usaha untuk memahami hadîth dari aspek tingkah laku sosial masyarakat pada saat itu. ${ }^{3}$ Dengan demikian, bisa dikatakan bahwa pendekatan sosiologis terhadap hadith adalah mencari uraian dan alasan tentang posisi masyarakat sosial yang berhubungan dengan ketentuan-ketentuan dalam hadîth. Penguasaan konsep-konsep sosiologi dapat memberikan kemampuan untuk mengadakan analisis terhadap efektivitas hạaîth dalam masyarakat, sebagai sarana untuk

\footnotetext{
2 Said Agil Husain al-Munawwar dan Abdul Mustaqim, Asbabul Wurud: Studi Kritis Atas Hadis Nabi, Pendekatan Sosio, Historis, Kontekstual (Yogyakarta: Pustaka Pelajar, 2001), 24-25.

3 Abdul Mustaqim, Ilmu Ma'anil Hadis: Paradigma Interkoneksi (Yogyakarta: Idea Press, 2009), 62.
} 
merubah masyarakat agar mencapai keadaan-keadaan sosial tertentu yang lebih baik.

Kajian tentang pemaknaan ḥadîth sebenarnya sudah muncul sejak kehadiran Nabi Muhammad, apalagi ketika beliau diangkat menjadi rasul dan menjadi panutan sahabat dan umat Islam. Karena para sahabat mahir dalam bahasa Arab, sehingga sabda-sabda Nabi bisa dipahami dengan mudah. Andaikan ada kesulitan dalam memahami sebuah hadìt, para sahabat tidak segan untuk langsung menanyakannya kepada Nabi Muhammad.

Posisi penting hadîth yang menjadi salah satu rujukan sumber hukum Islam menjadikannya penting untuk dikontekstualisir dengan semangat zaman, karena kenyataannya kajian dalam memahami hadîth sangat bervariasi. Hal ini juga dipengaruhi oleh beragam horizon masing-masing komunitas Muslim di berbagai daerah. Hasil keragaman pendapat tersebut memberikan klaim masing-masing bahwa keputusannya adalah sebagai suatu yang valid dan merujuk kepada Nabi Muhammad. ${ }^{4}$

Dengan pendekatan pemaknaan sosiologis hadîth di atas paling tidak bisa memberikan masukan kepada para pemerhati hadith pemahaman terhadap hadîth tidak hanya didasarkan pada teksnya saja, namun harus dikaitkan dengan semangat konteks dan sosialnya. Dalam konteks pemaknaan hadîth tentang wakaf, seharusnya masyarakat Muslim harus menyesuaikan dengan perkembangan kehidupan sosial dewasa ini, sehingga wakaf yang ada di sekitar kita menjadi produktif dan berkembang.

Demikian halnya dengan pemaknaan hadîth wakaf di kalangan ulama tradisional dan ulama modern di Gresik. Ulama tradisional lebih menekankan pemahaman dan pemaknaan hadîth wakaf secara tekstual, sedangkan ulama modern lebih menekankan pemahaman dan pemaknaan hadîth wakaf secara kontekstual. Perbedaan pendapat keduanya disebabkan latar belakang pendidikan mereka berbeda.

\section{Hadîth-ḥadîth tentang Wakaf}

Dalam sejarah perkembangan wakaf, ḥadîth-ḥadîth yang memuat masalah wakaf sangat banyak. Adapun yang dapat penulis sebut adalah sebagai berikut.

1. Riwayat hadîth yang paling terkenal memuat tentang wakaf adalah hadîth yang menceritakan wakaf 'Umar b. al-Khattâb.

${ }^{4}$ M. Syuhudi Ismail, Metodologi Penelitian Hadis Nabi (Jakarta: Bulan Bintang, 2007), 3. 


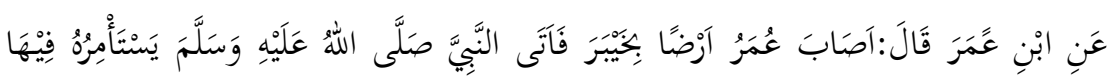

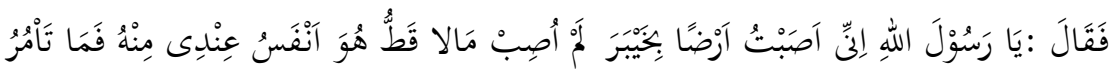

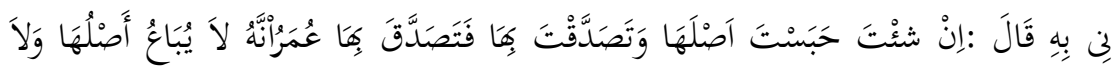

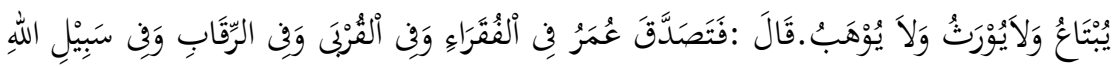

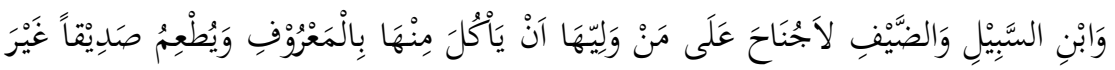
مُتَمَوِّلِ فِيْهِ .رواه مسلم 5.

"Dari Ibn 'Umar berkata: bahwa sahabat 'Umar memeroleh sebidang tanah di Khaybar, kemudian dia datang kepada Rasûl Allâh untuk memohon petunjuk. Umar berkata: Wahai Rasûl Allâh, saya telah mendapat sebidang tanah di Khaybar, saya belum pernah mendapatkan harta sebaik itu, maka apakah yang engkau perintahkan kepadaku? Rasûl Allâh menjawab: Bila kamu suka, kamu tahan (pokoknya) tanah itu, dan kamu sedekahkan (hasilnya). Kemudian 'Umar melakukan sedekah, tidak dijual, tidak dihibahkan dan tidak pula diwariskan. Berkata Ibn 'Umar: Umar menyedekahkannya kepada orang-orang fakir, kerabat, budak belian, sabîl Allâh, ibn al-sabîl, dan tamu. Tidak dilarang bagi yang menguasai tanah wakaf itu (pengelola) makan dari hasilnya dengan cara baik (sepantasnya) atau makan dengan tidak mermaksud menumpuk harta".

2. Wakaf yang telah dilakukan oleh Abû Talḩ̣ah kepada kerabatnya, antara lain kepada putra pamannya atas petunjuk Rasûl Allâh, seperti hạâth riwayat Imâm Bukhârî dari Ishâaq b. 'Abd. Allâh.

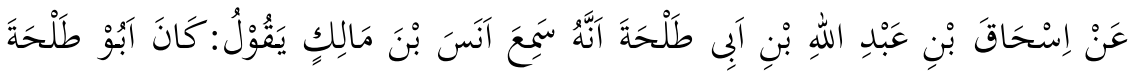

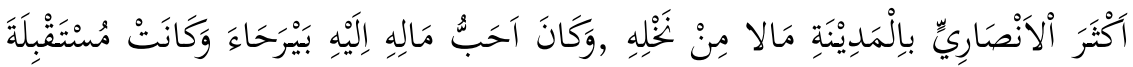

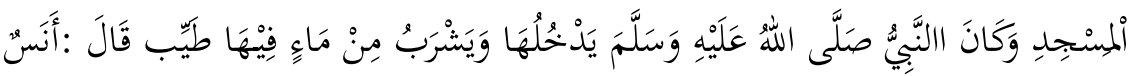

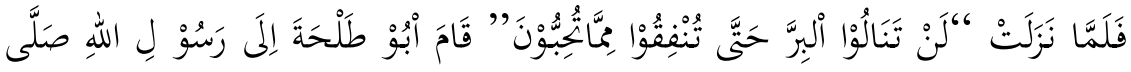

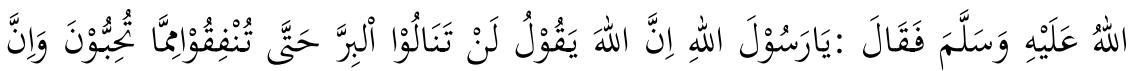

${ }^{5}$ Muslim b. al-Hajajâj b. Muslim al-Qushayrî al-Naysâbûrî, al-Jâmi al-Ṣahîh, Vol. 5 (Beirut: Dâr al-Fikr, 1993), 74; Bandingkan Abû 'Abd Allâh Muhammad b. Yazîd b. Mâjah al-Rabî al-Quzwaynî, Sunan Ibn Mâjah, Vol. 2 (Kairo: Dâr al-Hadîth, 1988), 801; Bandingkan Abû 'Abd al-Raḥmân Aḥmad b. Shu'ayb b. 'Alî b. Sinân b. Baḥr b. Dînâr al-Nasâ'î, Sunan al-Nasầ, Vol. 5 (Beirut: Dâr al-Kutub al-'Ilmîyah, 1995), 230; Bandingkan Abû Dâwud Sulaymân b. al-Ash'ath b. Ishâaq b. Bashîr al-Azdî alSijistânî, Sunan Abî Dâwud, Vol. 2 (Beirut: Dâr al-Kutub al-'Ilmîyah, 1996), 324-325. 


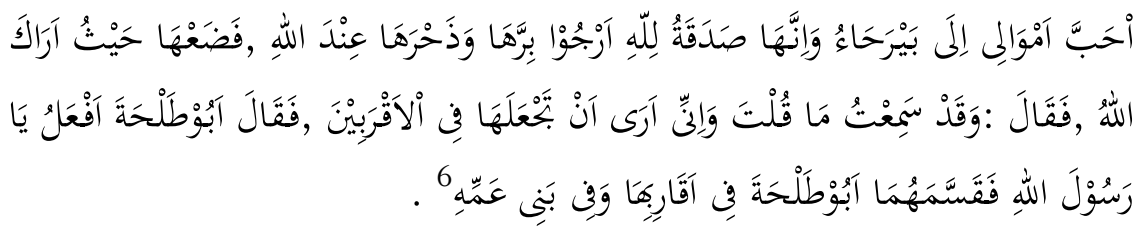

Diriwayatkan dari Ishâaq b. 'Abd Allâh b. Abî Talhah, bahwa ia mendengar Anâs b. Mâlik berkata: "Abû Talḥah adalah sahabat Anṣâr yang paling banyak kebun kurmanya di Madinah, harta yang paling ia cintai ialah bayraḥ̂a' yang berhadapan dengan masjid Nabi. Nabi pernah masuk ke dalam kebun itu untuk mengambil air jernih di situ. Setelah turun ayat, Anas berkata kepada Rasûl Allâh: "Wahai Rasûl Allâh, sesungguhnya Allah telah berfirman: "Kami sekali-kali tidak sampai kepada kebajikan yang sempurna sebelum kamu menafkahkan sebagian harta yang kamu cintai". Kemudian Abû Ṭalḥah menyambung, “.... sedang harta yang kami cintai adalah bayrahâa. Ia akan kami sedekahkan kepada Allah, saya berharap kebaikan dan menyimpannya di sisi Allah, karena itu pergunakanlah pada tempat yang engkau inginkan". Nabi bersabda: "Aku mengerti apa yang engkau katakan, menurut pendapatku, berikan saja harta itu kepada keluargamu. "Akan kami kerjakan wahai Rasûl Allâh”, jawab Abû Ṭalḥah. Kemudian ia membagi-bagikannya kepada sanak kerabat dan anak pamannya.

3. Sahabat 'Uthmân b. 'Affân pernah mewakafkan hartanya, ketika menyambut seruan Rasûl Allâh untuk membeli sumur rûwmah. Sebagaimana dalam hadîth riwayat al-Tirmîdhî:

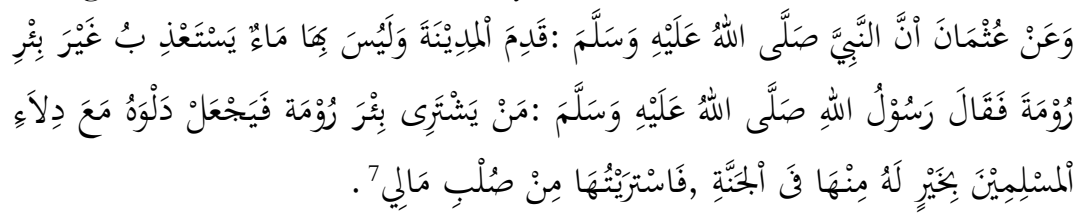

"Dari Uthmân, ketika Nabi datang ke Madinah, pada saat itu tidak ada air tawar kecuali sumur rummah, lalu Rasûl Allâh bersabda: "Siapakah yang mau membeli sumur ruwmah? Ia dapat mengambil air dengan timbanya dari sumur itu bersama-sama dengan kaum Muslimin lainnya, kelak ia akan mendapatkan sesuatu yang lebih baik dari sumur itu di surga". Kemudian sumur itu aku (Uthmân b. 'Affân) beli dengan kekayaan yang ada padaku".

4. Al-Bukhârî meriwayatkan dari Abû Hurayrah dengan sanad marfü

\footnotetext{
${ }^{6}$ Abû 'Abd Allâh b. Ismâîl b. Ibrâhîm b. al-Mughîrah Bardizbah al-Ju'fî al-Bukhârî, Șahîh al-Bukhârî, Vol. 3 (Beirut: Dâr al-Fikr, 1994), 258.

${ }^{7}$ Muhammad b. 'Îsa b. Sawrah b. Mûsâ b. al-Ḍahhậk al-Sullamî al-Tirmîdhî, Sunan al-Tirmîdhî, Vol. 5 (Beirut: Dâr al-Fikr, 1994), 393.
} 


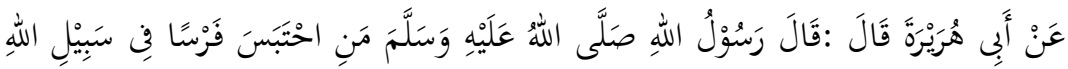

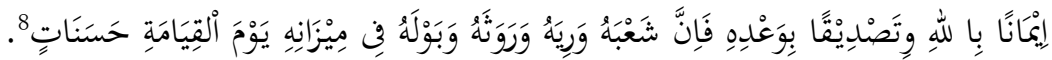

"Dari Abû Hurayrah berkata: Rasûl Allâh bersabda: Barangsiapa yang mewakafkan kudanya (untuk perang) dalam perjuangan di jalan Allah dengan penuh perasaan iman dan mengharap ridâ Allah, maka makanan, kotoran, dan air kencingnya di hari kiamat nanti dalam pertimbangannya akan terdapat beberapa kebaikan".

5. Imam Muslim meriwayatkan hadîth dari sahabat Abû Hurayrah:

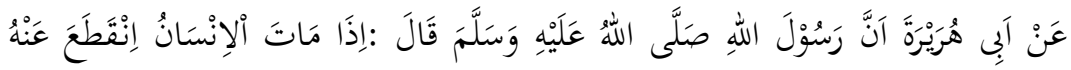

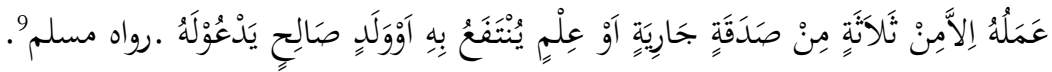

"Dari Abî Hurayrah, sesunguhnya Rasûl Allâh bersabda: Apabila manusia wafat, terputuslah amal perbuatannya, kecuali dari tiga hal, yaitu sedekah jariyah, ilmu yang bermanfat, dan anak yang saleh".

\section{Pemaknaan Wakaf dalam the Living Hadîth di Kalangan Ulama Tradisional dan Modern di Gresik}

\section{Ulama Tradisional Gresik}

Pemaknaan hadîth wakaf di kalangan ulama tradisional perlu penulis kemukakan berdasarkan dengan urutan hạaith di atas.

Pertama, hadîth riwayat Imam Muslim dari Ibn 'Umar.

Ada beberapa hal penting yang harus diperhatikan dalam hadîth di atas menurut pemaknaan ulama tradisional. ${ }^{10}$ Seperti pernyataan:

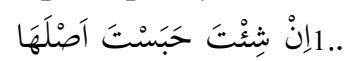

"Bila kamu suka, kamu tahan (pokoknya) tanah itu",

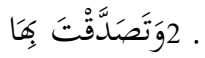

"Dan kamu sedekahkan (hasilnya)".

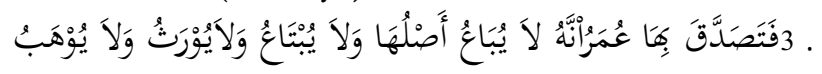

"Kemudian Umar melakukan sedekah, tidak dijual, tidak pula diwariskan dan, tidak dihibahkan".

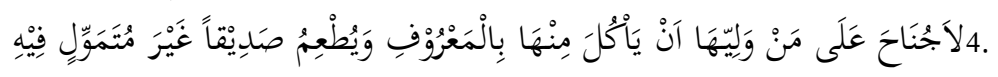

\footnotetext{
8 al-Bukhârî, Sabîh al-Bukhârî, Vol. 3, 204.

9 Muslim b. al-Ḥajjâj b. Muslim al-Qushayrî al-Naysâbûrî, Saḅ̂h Muslim, Vol. 2 (Bandung: Dahlan, t.th.), 14.

${ }^{10}$ Farhan, Wawancara, Gresik, 4 Januari 2014.
} 
“Tidak dilarang bagi yang menguasai tanah wakaf itu (pengelola) makan dari hasilnya dengan cara baik (sepantasnya) atau makan dengan tidak mermaksud menumpuk harta".

Kalimat nomor 1 dan 2 di atas menunjukkan bahwa benda yang diwakafkan apakah bendanya yang disebut dalam hadîth dengan istilah al-asl (manfaatnya) yang disebut thamratuhâ (hasilnya) saja. Sementara nomor 3 menunjukkan bahwa benda yang diwakafkan itu tidak boleh dijual, dijual-belikan, diwariskan dan dihibahkan. Sedang nomor empat menunjukkan kepastian adanya wali atau nâdir wakaf. Si wali atau nâdir pun diperbolehkan menggunakan atau memakan sebagian dari benda wakaf itu dengan syarat, tidak ada maksud untuk memilikinya, dan hanya sekedarnya dalam arti tidak dengan maksud untuk memupuk harta kekayaan.

Adapun pemaknaan pernyaatan Nabi ḥabas ablabâ menurut ulama tradisional ${ }^{11}$ menimbulkan pertanyaan, "apakah Khaybar itu berstatus milik 'Umar atau sudah lepas dari kepemilikannya dikarenakan statusnya kini menjadi tanah wakaf'. Dalam memahami pernyataan Nabi sebagai tercantum dalam hadîth tersebut muncul beberapa interpretasi. Kata ḥabs dalam definisi di atas adalah batasan untuk mengecualikan harta-harta yang tidak masuk sebagai harta wakaf, sebagaimana seorang pemberi jaminan adalah masih memiliki harta yang ada di tangan orang lain (yang diberikan jaminan). Si penerima jaminan ini, haknya tetap ada dalam harta yang sama, dan kalau ia meninggal bisa diwariskan.

Kata ḅabs dalam hadith di atas adalah batasan untuk mengecualikan harta-harta yang tidak masuk sebagai harta wakaf, sebagaimana seorang pemberi jaminan adalah masih memiliki harta yang ada di tangan orang lain (yang diberikan jaminan). Si penerima jaminan ini, haknya tetap ada dalam harta yang sama, dan kalau ia meninggal bisa diwariskan.

Pemaknaan di atas adalah untuk menjabarkan bentuk wakaf yang pasti, sebagaimana pemahaman Abû Ḥanîfah. Akan tetapi kalau ditelaah lebih jauh, pada dasarnya pengertian-istilah menurut fuqahâ'-dengan memakai kata ḥabs itu menurut ulama tradisional ${ }^{12}$ tidak tepat untuk mendefinisikan bentuk wakaf yang pasti. Sebab kenyataan pada bentuk wakaf ini tidak ada penahanan harta. Sebab

${ }^{11}$ Syueb Zunaidi, Wawancara, Gresik, 4 Januari 2014.

12 Abd. Aziz, Wawancara, Gresik, 11 Januari 2014. 
harta wakaf tersebut masih bisa dipakai untuk jual beli, hibah, dan usaha pemindahan hak milik yang lainnya. Maksudnya, harta wakaf tersebut benar-benar ditahan (sebagai hak Allah). Persoalan ini kemudian dibantah oleh Burhân al-Dîn bahwa harta wakaf mesti bisa ditarik kembali oleh pemiliknya, selama dia masih hidup, tetapi hukumnya makrûh. ${ }^{13}$ Demikian juga ulama tradisional juga sebagian kecil mendukung apa yang telah dikemukakan Burhân al-Dîn. ${ }^{14}$

Pemaknaan kata habs (menahan) menurut ulama tradisiona ${ }^{15}$ mengutip pendapat Ibn Hammâm tidak perlu, karena dalam wakaf seperti ini orang masih bisa menjual harta jika dia menginginkan. Begitu pula, hak kepemilikan masih ada pada pemilik, sebagaimana sebelum dia memberikan manfaat harta itu sebagai sedekah. Sebab wâqif (orang yang mewakafkan) hanya menyatakan keinginan untuk menyedekahkan manfaat harta, maka dia bisa memutuskan amal sekehendaknya, sama seperti sebelum dia mewakafkannya. ${ }^{16}$

Pemaknaan kata habs (menahan) menurut ulama tradisional dengan berpedoman pada mazhab Mâlikî bahwa seseorang yang mewakafkan hartanya dapat menahan penggunaan harta benda tersebut secara penuh dan membolehkan pemanfaatan hasilnya untuk tujuan kebajikan, dengan tetap kepemilikan harta pada diri orang yang mewakafkan. ${ }^{17}$ Adapun masa berlakunya harta yang diwakafkan tidak untuk selamanya, melainkan hanya untuk jangka waktu tertentu sekehendak pewakaf saat mengucapkan sîghat (akad) wakaf. Oleh karenanya bagi mazhab Mâlikî tidak disyaratkan wakaf selamalamanya. Yang menjadi dasar pendapat mazhab Mâlikî bahwa pemilikan harta wakaf itu tetap berada di tangan orang yang mewakafkan dan manfaat bagi yang menerima hasil atau manfaat wakaf ialah hadith Nabi habbis al-aslaḥ wa-sabbil al-thamrah. ${ }^{18}$

Namun sebagian besar ulama tradisional mendukung pendapat mazhab Shâfîi bahwa status kepemilikan harta wakaf tidak lagi

\footnotetext{
${ }^{13}$ Ibrâhîm b. Mûsa b. Abî Bakr b. al-Shaykh 'Alî al-Ṭarablîshû al-Hanafî, al-Is'âf fî̀ A ḥkâm al-Awqâf (Mesir: Maktabat l-Kubrâ, t.th.), 3.

14 Tohir, Wawancara, Gresik, 11 Januari 2014.

15 Abd. Mujib, Wawancara, Gresik, 18 Januari 2014.

16 Al-Kamâl b. Hammâm Muhammad b. 'Abd al-Wâhịid b. 'Abd al-Ḥamîd b. Mas'ûd al-Siwâsî, Fatḥ al-Qadîr, Vol. 5 (Mesir: Musțafâ Muhammad, t.th.), 4.

17 Abd. Choliq, Wawancara, Gresik, 11 Januari 2014.

18 Muhammad al-Khatîib al-Sharbînî, Mughnî al-Mubtâj, Vol. 2 (Mesir: Muṣtafâ alBâbî al-Halabî, 1958), 376. Bandingkan Ibn Qudâmah, al-Mughnî, Vol. 8 (Mesir: Hajar, 1989), 186.
} 
menjadi milik orang yang mewakafkan, dan bukan hak milik nâżir (pengelola), akan tetapi kepemilikan harta wakaf menjadi hak Allah (untuk kepentingan umat Islam). ${ }^{19}$ Mazhab Hanbalî memberikan pemahaman bahwa apabila harta sudah diwakafkan oleh orang yang mewakafkan, maka status kepemilikan harta tersebut sudah tidak lagi menjadi pemiliknya, tidak boleh dijual, dihibahkan, dan diwariskan. Pendapat mazhab Shâfîî dan mazhab Mâlikî adalah pendapat yang paling banyak didukung oleh ulama tradisional. ${ }^{20}$

Kedua, hạadîth riwayat Imam Bukhârî dari Abû Ṭalḥah.

Ulama tradisional memberikan pemaknaan terhadap hadîth riwayat Imam Bukhârî dari Abû Ṭalhahah adalah wakaf dhurrî, ${ }^{21}$ yaitu wakaf yang diperuntukkan bagi orang-orang yang tertentu yang umumnya terdiri atas keluarga atau anggota keluarga dan keturunan orang yang mewakafkan. Oleh karena itu, wakaf jenis ini seringkali disebut wakaf abli yang secara harfìjah berarti wakaf untuk keluarga.Wakaf macam ini dipandang sah, dan yang berhak menikmati harta wakaf itu adalah mereka yang ditunjuk dalam pernyataan wakaf. Jika di kemudian hari anak-anak dan keturunan orang yang mewakafkan tidak ada lagi atau terputus, siapa yang mengurus harta wakaf.

Jika terjadi semacam itu, seharusnya kembali pada syarat bahwa wakaf tidak boleh dibatasi dengan waktu tertentu, meskipun anak keturunan orang yang menjadi tujuan wakaf itu tidak ada lagi yang mampu menggunakan, maka kedudukan wakaf yang dipergunakan keluarga orang yang mewakafkan akan dikembalikan untuk wakaf khayrî (wakaf umum). ${ }^{22}$

Kelanjutan dan penetapan pendayagunaan wakaf dburrî yang berubah statusnya menjadi wakaf khayrî ada di tangan kewenangan hakim: apakah peruntukannya ditujukan untuk kepentingan ibadah, seperti masjid, kepentingan sosial, seperti rumah sakit, sekolah, dan sebagainya. ${ }^{23}$

\footnotetext{
${ }^{19}$ Moh. Sobir, Wawancara, Gresik, 25 Januari 2014.

${ }^{20}$ Syuhel, Wawancara, Gresik, 25 Januari 2014.

${ }^{21}$ Bachruddin, Wawancara, Gresik, 25 Januari 2014.

22 Muḥammad Abû Zahrah, Muḥạdarât fî̀ al-Waqf (Beirut: Dâr al-Fikr al-'Arabî, 2005), 86.

${ }^{23}$ Juhaya S. Praja, Hukum Wakaf di Indonesia (Bandung: Yayasan Piara, 1995), 30.
} 
Prinsipnya pemaknaan wakaf keluarga menurut ulama tradisional juga mempunyai kandungan makna kebaikan dan kebaktian, ${ }^{24}$ karena merupakan salah satu bentuk kebaikan bagi generasi yang akan datang, meningkatkan kesejahteraannya atau paling tidak dapat meringankan beban ekonomi yang dipikulnya. Adapun perlakuan tidak baik yang kadang muncul terhadap wakaf keluarga dari para nâdir, karena faktor terlalu lama mengurus wakaf atau tidak adanya badan pengawas yang mengontrol kinerja wakaf keluarga atau tidak adanya lembaga fatwa yang mengarahkan kegiatannya. Semua itu hendaknya tidak dijadikan sikap negatif terhadap wakaf keluarga, dan juga bukan berarti bahwa wakaf keluarga mendapat perhatian yang berlebihan sehingga tidak terkesan sangat dimanja. Dalam hal ini perlu dibuat undang-undang yang memuat bab khusus tata cara pelaksanaan wakaf keluarga baru dan memberi perlindungan hukum yang jelas, terutama dari berbagai hal yang berbentuk upaya pengerusakan, baik dari para nâdir atau orang yang berhak atas manfaat wakaf tersebut, atau dari berbagai pihak lainnya.

Ketiga, hadîth riwayat Imam al-Tirmîdhî dari 'Uthmân b. 'Affân.

Pemaknaan hadîth riwayat Imam al-Tirmîdhî dari 'Uthmân b. 'Affân menurut ulama tradisional termsuk kelompok wakaf khayrî (wakaf umum). ${ }^{25}$ Wakaf khayrî (wakaf umum) inilah yang sejalan dengan jiwa amalan wakaf yang amat digembirakan dalam ajaran Islam, yang pahalanya akan terus mengalir, meskipun orang yang mewakafkan telah meninggal dunia, selama harta wakaf masih tetap dapat dimanfaatkan. Wakaf khayrî (wakaf umum) adalah benar-benar dapat dinikmati hasilnya oleh masyarakat secara luas dan merupakan salah satu sarana untuk menyelenggarakan kesejahteraan masyarakat, baik dalam bidang sosial, ekonomi, pendidikan, kebudayaan, dan kepentingan umat Islam.

Dalam segi penggunaannya, wakaf jenis ini jauh lebih banyak manfaatnya dibanding dengan wakaf keluarga, karena tidak terbatasnya pihak-pihak yang ingin mengambil manfaat. Jenis wakaf inilah yang sesungguhnya paling sesuai dengan tujuan perwakafan itu sendiri secara umum. Dalam jenis wakaf ini juga, orang yang mewakafkan dapat mengambil manfaat dari harta yang diwakafkan, seperti wakaf masjid dan wakaf sumur.

\footnotetext{
24 Muhammad Basyir, Wawancara, Gresik, 4 Januari 2014.

${ }^{25}$ Hasan Bisyri, Wawancara, Gresik, 25 Januari 2014.
} 
Secara substansinya, menurut ulama tradisional, ${ }^{26}$ wakaf inilah yang merupakan salah satu segi dari cara memanfaatkan harta di jalan Allah. Tentunya kalau dilihat dari manfaat kegunaannya merupakan salah satu sarana pembangunan, baik di bidang keagamaan, khususnya peribadatan, perekonomian, kebudayaan, kesehatan, keamanan, dan sebagainya. Dengan demikian, benda wakaf tersebut benar-benar terasa manfaatnya untuk kepentingan kemanusiaan, tidak hanya untuk keluarga atau kerabat yang terbatas.

Keempat, hadîth riwayat Imam Bukhârî dari Abû Hurayrah.

Ulama tradisional memberi pemaknaan hadîth riwayat Imam Bukhârî dari Abû Hurayrah adalah wakaf benda bergerak (al-manqû́). ${ }^{27}$ Mereka mendukung perbedaan pendapat fuqahâ', di antaranya mazhab Hanafî menolak wakaf benda bergerak, karena ada ketentuan yang dikenal di kalangan mereka bahwa "benda yang sah diwakafkan hanya yang tidak bergerak". Ketentuan tersebut menjadi dasar yang paling berpengaruh dalam wakaf, yaitu ta'bîd (tahan lama). Namun demikian mazhab Hanafi memerbolehkan wakaf benda bergerak dalam beberapa hal, sebagai pengecualian dari prinsip tersebut antara lain:

a. Apabila keadaan harta bergerak tersebut mengikuti benda yang tidak bergerak. Dalam hal ini ada dua macam. Pertama, barang tersebut mempunyai hubungan dengan sifat diam di tempat dan tetap. Misalnya, bangunan dan pohon, keduanya termasuk benda bergerak yang bergantung pada benda bergerak. Kedua, benda bergerak yang digunakan untuk membantu benda yang tidak bergerak, seperti alat untuk membajak dan kerbau yang digunakan untuk membajak.

b. Apabila wakaf harta yang bergerak itu ada nass yang memerbolehkannya, seperti senjata dan kuda atau binatangbinatang yang digunakan untuk berperang.

c. Apabila benda yang bergerak itu sudah menjadi kebiasaan masyarakat banyak mewakafkannya. Seperti wakaf buku (kitab) dan mușhaf (al-Qur'ân). ${ }^{28}$

Mazhab Mâlikî tidak membedakan wakaf barang tetap dan barang tidak tetap. ${ }^{29}$ Menurut mereka boleh mewakafkan segala sesuatu yang

${ }^{26}$ Misbach, Wawancara, Gresik, 4 Januari 2014.

${ }^{27}$ Syueb Zunaidi, Wawancara, Gresik, 4 Januari 2014.

${ }^{28}$ Abû Zahrah, Muḥậarât, 103.

29 'Alî Fikrî, al-Mu'âmalât al-Mâdiyah wa al-Adâbîyah, Vol. 2 (Mesir: Muștafâ al-Bâbî alHalabî, 1938), 307. 
dapat memberikan manfaat kepada orang yang diberi wakaf, baik berupa benda tetap maupun tidak tetap, untuk selamanya atau untuk jangka waktu tertentu.

Berbeda dengan pendapat mazhab Hanafî dan Mâlikî, mazhab Shâfíî tidak memberikan batasan terhadap batasan terhadap aset yang akan diwakafkan. Menurut mereka, bahwa barang yang diwakafkan haruslah barang yang kekal manfaatnya, baik berupa aset barang tidak bergerak maupun yang bergerak. ${ }^{30}$ Menurut mazhab Ḥanbalî, barang yang sah diperjualbelikan, sah pula diwakafkan dan bermanfaat secara mubah, sedang bentuk barangnya kekal.

Kelima, hạaîth riwayat Imam Muslim dari Abû Hurayrah

Allah telah mensharî̀‘ahkan wakaf, menganjurkan dan menjadikannya sebagai salah satu cara untuk mendekatkan diri kepada-Nya. ${ }^{31}$ Wakaf merupakan salah satu ibadah yang tujuan pokoknya adalah untuk mendapatkan ridâ dari Allah. Oleh karena itu wakaf dibenarkan selama digunakan pada hal-hal yang diperbolehkan sharî‘'ah Islam.

Menurut ulama tradisional, ${ }^{32}$ kedudukan wakaf digolongkan sebagai sadaqah jâriyah, yakni menyedakahkan harta yang bertujuan sebagai ibadah atau amal kebaikan yang pahahalanya akan terus mengalir walaupun yang bersangkutan telah meninggal dunia, selama harta yang diwakafkan masih bermanfaat.

Șadaqah jâriyah, menurut mereka, adalah menyedekahkan harta yang tahan lama, untuk maksud-maksud kebaikan hingga manfaatnya dapat terus dinikmati, meskipun orang yang bersedekah telah meninggal dunia. Misalnya, mendirikan tempat-tempat ibadah, rumah sakit, sekolah, membuat sumur untuk umum, membuat parit untuk irigasi umum, menyedekahkan tanah untuk jalan umum dan sebagainya.

Walaupun hadîth di atas tidak menyebutkan wakaf, namun para ulama telah sepakat bahwa yang dimaksud dengan sadaqah jâriyah (yang mengalir) dalam hadîth tersebut adalah wakaf. ${ }^{33}$ Hal ini juga dikemukakan oleh al-Ṣan'ânî dalam kitab Subul al-Salâm, hadîth

${ }^{30}$ al-Sharbînî, Mughnî al-Muhtâj, Vol. 3, 376.

31 Sayyid Sâbiq, Fiqh al-Sunnah, Vol. 3 (Mesir: Dâr al-Fath li-I'lâm al-'Ilmîyah, t.th.), 406.

32 Abd. Mujib, Wawancara, Gresik, 18 Januari 2014.

33 Muslim b. al-Ḥajjâj b. Muslim al-Qushayrî al-Naysâbûrî, al-Jâmi al-Ṣaḅ̂h, Vol. 5 (Beirut: Dâr al-Fikr, 1993), 73. 
tersebut dikemukakan di dalam bab wakaf, karena ulama menafsirkan sadaqah jâriyah (yang mengalir) dengan wakaf. ${ }^{34}$

\section{Ulama Modern Gresik}

Ulama tradisioanal memberikan pemaknaan hadîth wakaf secara tekstual dan rinci, sedangkan pemaknaan hadîth wakaf menurut ulama modern lebih menekankan kepada pemaknaan kontekstual dan global. Pemaknaan hadith wakaf adalah investasi harta wakaf, ${ }^{35}$ yang berarti memanfaatkannya untuk berbagai keperluan investasi dalam rangka mencapai tujuan wakaf dan menjaga keutuhan wakafnya adalah sebuah keharusan. Sebab apabila hal ini bukan sebuah kewajiban, wakaf tidak akan bertahan lama. Karena itu wakaf dibentuk untuk merealisir tujuannya. Apabila dibiarkan dan tidak digunakan untuk mencapai tujuan, maka keberadaan lembaga wakaf menjadi tidak memiliki arti.

Harta wakaf, baik langsung maupun tidak langsung ditahan untuk meningkatkan manfaaat dan hasilnya adalah untuk merealisasikan tujuan yang ditentukan oleh wâqif (orang yang mewakafkan). Menghentikan manfaat harta wakaf atau hasilnya berarti menghalangi tercapainya tujuan wakaf dari hak-hak yang diberikan Allah ketika memerbolehkan pembentukan wakaf, bahkan menganjurkan dan menjanjikannya dengan pahala yang tidak terputus, sekalipun untuk dimanfaatkan oleh wâqif sendiri. Sebab kalau tidak diperbolehkan berarti telah melarang wâqif untuk mendapatkan hak-haknya.

Sedangkan pemaknaan hadîth wakaf bagi ulama modern, pemberhentian fungsi wakaf dari kerja yang semestinya berarti telah menyia-nyiakan potensi produksi yang ada pada harta wakaf dan melarang masyarakat untuk mendapatkan kebaikan wakaf yang berupa barang atau pelayanan yang diberikan sebagai hasil investasi wakaf. Pemberhentian fungsi wakaf juga berarti menyumbat modal sosial yang ada pada wakaf tersebut. Demikian juga pada wakaf langsung, pemberhentian fungsi wakaf sehingga tidak dapat dipergunakan lagi berarti menghalangi masyarakat dari manfaatnya, yang mungkin kalau dirawat bisa dipergunakan untuk tempat salat berjemaah, atau dipergunakan sebagai rumah sakit atau tempat belajar siswa. ${ }^{36}$

\footnotetext{
34 Muḥammad b. Ismầîl al-Kahlanî al-Ṣan'ânî al-Yamanî, Subul al-Salâm, Vol. 3 (Bandung: Multazam, t.th.), 87.

${ }^{35}$ Nashun Amin, Wawancara, Gresik, 4 Januari 2014.

${ }^{36}$ Kamaly Manan, Wawancara, Gresik,12 Januari 2014.
} 
Dengan demikian tidak dapat diragukan lagi menurut ulama modern bahwa kewajiban memanfaatkan harta wakaf adalah kewajiban yang mendesak. Sebab menurut ulama modern, apapun bentuk pemberhentian fungsi wakaf, baik dalam jangka waktu panjang maupun pendek berarti melarang para pengguna wakaf untuk mendapatkan hak-hak dan kebaikannya dalam harta wakaf itu sendiri. ${ }^{37}$

Ulama modern juga tidak meragukan lagi bahwa kewajiban ini pertama kali menjadi tanggung jawab nâdir (pengelola harta wakaf) atau pihak terkait (badan wakaf Indonesia) selaku pengawas kegiatan wakaf tersebut. ${ }^{38}$ Barangkali kurang pahamnya peraturan wakaf di Indonesia secara rinci dan pemaknaan yang jelas tentang kewajiban nâdir dan tanggung jawabnya, serta belum adanya kejelasan peran badan pengawas dan campur tangan langsung dari pemerintah yang terkait telah menyebabkan berhentinya fungsi dari berbagai bentuk wakaf, sehingga tidak lagi dapat menghasilkan sesuatu yang diharapkan.

Untuk mengetahui prinsip-prinsip umum dalam pemaknaan hadith wakaf, ulama modern membedakan antara pemaknaan pengembangan dan memanfaatkan harta wakaf. ${ }^{39}$ Pengembangan dimaksudkan untuk menambah jumlah harta yang dipekerjakan atau diinvestasikan atau modal wakaf. Misalnya ada wakaf tanah pemukiman yang berhenti fungsinya, maka kita perlu menginvestasikannya dengan cara membangun yang bermanfaat bagi masyarakat setempat di pemukiman itu. Misalnya, ada wakaf tanah pemukiman yang terhenti dan kurang berfungsi, maka menurut mereka perlu menginvestasikannya dengan cara membangun pertokoan untuk keperluan masyarakat, dan hasilnya akan dimanfaatkan pada pengembangan harta wakaf selanjutnya.

Sedangkan memanfaatkan harta wakaf menurut ulama modern adalah upaya mengaktifkan penggunaan wakaf dalam mencapai tujuannya. ${ }^{40}$ Karena itu wakaf yang akan dipekerjakan memerlukan persiapan untuk mengemban tugas ini. Sebuah contoh untuk mengaktifkan sekolah, diperlukan dana untuk menggaji guru-guru yang akan mengajar, keperluan alat tulis yang layak, alat peraga dan

\footnotetext{
${ }^{37}$ Muhammad Zaini, Wawancara, Gresik, 19 Januari 2014.

${ }^{38}$ Nur Rochim, Wawancara, Gresik, 26 Januari 2014.

${ }^{39}$ Khoiruddin, Wawancara, Gresik, 5 Januari 2014.

40 Afif, Wawancara, Gresik, 12 Januari 2014.
} 
peralatan lainnya yang diperlukan. Demikian juga masjid dan rumah sakit yang ingin diaktifkan fungsinya, bangunan tempat tinggal yang akan disewakan, dan hasil bersihnya diberikan sesuai dengan tujuan wakaf.

Keperluan akan dana untuk kembali mengaktifkan wakaf menurut ulama modern sebenarnya bertujuan agar pengelola wakaf dapat menginvestasikan modal wakaf. Sebuah contoh wakaf memerlukan perawatan. ${ }^{41}$ Pada saat seperti ini pengelola wakaf dapat menyisihkan sebagian dari hasil wakaf untuk biaya perawatannya, atau meminjam terlebih dahulu dari kas wakaf dan diganti dengan sebagian hasil yang sengaja di sisihkan untuk keperluan itu. Bisa juga ada tanah wakaf pertanian yang memerlukan benih atau pupuk sekaligus, maka dalam kondisi tidak ada dana, nâdir diperbolehkan meminta bantuan yang berasal dari sumber dana halal, dan kalau sudah panen dana tersebut harus dikembalikan.

Jika kita teliti lebih detail, menurut ulama modern sangat sulit untuk membuat standar yang jelas dalam membedakan dua bentuk pendanaan ini pada beberapa kondisi yang sangat mendesak. ${ }^{42}$ Sebab suatu saat dana perawatan sangat besar, dan belum tentu dapat tertutupi selama beberapa tahun, akan tetapi pada saat yang sama dana tersebut tidak menambah nilai modal wakaf. Sebagaimana dana perawatan terkadang sedikit dan bisa diambil dari hasil produksi selama satu musim, karena pada saat itu telah membuat tambahan modal pada wakaf.

Setelah dipahami dari beberapa definisi wakaf menurut ulama modern secara terminologis, maka perlu dikemukakan definisi wakaf yang sesuai dengan hakikat hukum, muatan ekonomi, dan peranan sosialnya. Bagi mereka, wakaf adalah menahan harta baik secara abadi maupun sementara, untuk dimanfaatkan langsung atau tidak langsung, dan diambil manfaat hasilnya secara berulang-ulang untuk kebaikan umum maupun khusus. ${ }^{43}$

Dalam pemaknaan hadîth wakaf menurut ulama modern di atas telah dipaparkan secara menyeluruh semua bentuk dan jenis wakaf. Menurut mereka pemaknaan wakaf sesuai dengan hukum, muatan ekonomi, dan peranan sosialnya. Pertama, adalah menahan harta untuk dikonsumsi atau dipergunakan secara pribadi. Ini menunjukkan bahwa

\footnotetext{
${ }^{41}$ Midhhar, Wawancara, Gresik, 19Januari 2014.

${ }^{42}$ Syaiful, Wawancara, Gresik, 26 Januari 2014.

${ }^{43}$ Kholif, Wawancara, Gresik, 5 Januari 2014.
} 
wakaf berasal dari modal yang bernilai ekonomi dan bisa memberikan manfaat, seperti manfaat untuk salat yaitu untuk masjid, manfaat tempat belajar yaitu sekolah, manfaat bagi orang bepergian yaitu kendaraan. Modal yang bernilai ekonomi ini juga bisa sesuatu yang dapat menghasilkan barang, seperti buah dan biji-bijian, atau seperti air sumur dan hasil produksi. Maka setiap barang yang bermanfaat atau menghasilkan barang disebut modal. Hal ini menurut pengertian ekonomi. ${ }^{44}$

Wakaf adalah sesuatu yang dapat memberikan manfaat secara berulang-ulang untuk tujuan tertentu selama beberapa kurun waktu sama dengan wakaf modal yang menghasilkan berbagai manfaat tersebut. Karena itulah wakaf merupkan nilai ekonomi saat ini dan akan mendatangkan banyak manfaat wakaf di masa yang akan datang. Di antara contoh wakaf seperti ini adalah wakaf barang atau pelayanan secara berulang-ulang selama beberapa kurun waktu tertentu, seperti wakaf buku secara berkala (wakaf barang) dan wakaf hak pemakaian jalan secara berkala (wakaf manfaat). Ini juga merupakan modal produktif yang dapat menghasilkan pelayanan atau barang di masa yang akan datang. Singkatnya, pengertian "menahan" adalah menahan dari konsumsi, kerusakan, jual beli dan semua tindakan yang bersifat pribadi. Namun tujuan penahanannya untuk tujuan tertentu dan itu hanya satu, yaitu memanfaatkan untuk kebaikan.

Kedua, definisi wakaf itu mencakup harta. ${ }^{45}$ Harta ada kalanya tetap dan tidak bisa bergerak seperti tanah dan bangunan, dan ada kalanya berupa benda bergerak, seperti buku dan senjata. Bisa berupa barangbarang peralatan dan kendaraan, atau berupa uang seperti deposito dan pinjaman, bisa juga berupa manfaat yang mempunyai nilai uang seperti manfaat pengangkutan khusus orang sakit dan lanjut usia, atau berupa manfaat dari harta benda tetap yang diwakafkan oleh penyewa. Karena manfaat tersebut sudah menjadi miliknya, seperti manfaat pemakaian jalan, dan manfaat tanah lapang yang dijadikan tempat salat 'Îd al-Fitrî dan 'Îd al-Aḍhạ secara berulang-ulang.

Ketiga, mengandung pemaknaan melestarikan harta dan menjaga keutuhannya, sehingga memungkinkan untuk dimanfaatkan secara langsung atau diambil manfaat hasilnya secara berulang-ulang, ${ }^{46}$ seperti sawah, tambak (untuk perikanan), dan tanah tegalan. Dengan

\footnotetext{
${ }^{44}$ Suwanto, Wawancara, Gresik, 12 Januari 2014

${ }^{45}$ Kamaly Manan, Wawancara, Gresik, 12 Januari 2014.

${ }^{46}$ Nur Rochim, Wawancara, Gresik, 26 Januari 2014.
} 
demikin, definisi ini menerangkan kelanjutan adanya harta atau benda yang diwakafkan, sehingga dapat memberi manfaat dan sedekah yang terus berjalan seperti yang digambarkan oleh Nabi Muhammad. Pengertian menjaga dalam definisi ini juga mencakup makna melindungi kepengurusan dan nilai ekonomi barangnya, sehingga wakaf dapat menghasilkan manfaat sesuai dengan tujuan wakaf itu sendiri.

Keempat, pemaknaan hadîth wakaf tersebut mengandung pengertian berulang-ulangnya manfaat dan berkelanjutan, baik berlangsung lama, sebentar atau selamanya. ${ }^{47}$ Adanya manfaat yang berulang-ulang dan berkelanjutan mengandung pengertian bahwa wakaf tersebut berjalan. Keberlangsungan wakaf tergantung pada jenis wakafnya atau batasan waktu yang ditetapkan oleh wâqif, terkecuali sedekah biasa dan bersifat sederhana yang biasanya dimanfaatkan sekali secara langsung dengan cara menghabiskan barangnya. Jadi sedekah disebut jariyah apabila berlangsung atau selama manfaat wakaf dapat dimanfaatkan secara berulang-ulang, walaupun dalam waktu yang tidak sangat lama, maka itu juga disebut sadaqah jâriyah. Waktu keberlangsungan wakaf yang berkali-kali, maka akan dapat dimanfaatkan secara berulang-ulang tergantung pada jenis wakaf dan batasan waktu yang ditentukan oleh wâqif.

Kelima, pemaknaan hadîth wakaf mencakup wakaf langsung, ${ }^{48}$ yang menghasilkan manfaat langsung dari harta atau benda yang diwakafkan. Demikian juga mencakup wakaf produktif yang memberi manfaat dari hasil produksinya, baik berupa barang maupun jasa serta menyalurkan semua laba bersihnya sesuai dengan tujuan wakaf.

Keenam, pemaknaan hadîth wakaf mencakup jalan kebaikan umum keagamaan, sosial dan sebagainya, ${ }^{49}$ sebagaimana juga mencakup kebaikan khusus yang manfaatnya kembali kepada keluarga dan keturunannya, atau orang lain yang masih ada hubungan dengan wâqif.

Ketujuh, pemaknaan ḥadîth wakaf mencakup pentingnya penjagaan dan kemungkinan bisa diambil manfaatnya secara langsung atau dari manfaat hasilnya. ${ }^{50}$ Ini menentukan tugas yang mendasar bagi kepengurusan wakaf, dan perannya dalam menjaga kelestariannya dan

\footnotetext{
${ }^{47}$ Muhammad Zaini, Wawancara, Gresik, 19 Januari 2014.

${ }^{48}$ Nasihun Amin, Wawancara, Gresik, 5 Januari 2014.

${ }^{49}$ Syaiful, Wawancara, Gresik, 26 Januari 2014.

${ }^{50}$ Suwanto, Wawancara, Gresik, 12Januari 2014.
} 
menyalurkan manfaatnya bagi orang-orang yang berhak menerima wakaf baik dari masyarakat umum maupun kelompok khusus.

\section{Penutup}

Pemaknaan hadîth wakaf di kalangan ulama tradisional termasuk sadaqah jariyah. Menurut mereka, pemahaman ini didasarkan pada pendapat para ulama mazhab, kecuali mazhab Maliki yang menyatakan wakaf tidak terjadi bila orang yang mewakafkan bermaksud mewakafkan barangnya untuk selama-lamanya. Apabila orang yang mewakafkan itu membatasi waktunya untuk jangka waktu tertentu, misalnya mengatakan "Saya wakafkan barang ini untuk waktu sepuluh tahun," atau "saya membutuhkannya", atau "dengan syarat bisa saya tarik kembali kapan saja saya mau", atau "saya membutuhkannya", atau "anak saya membutuhkannya", dan redaksi semacam itu, maka apa yang dilakukannya itu tidak bisa disebut sebagai wakaf dalam pengertiannya yang benar.

Pemaknaan hadith wakaf di kalangan ulama modern adalah menahan harta yang "nampak/ada" baik secara abadi maupun sementara, untuk dimanfaatkan langsung atau tidak langsung, dan diambil manfaat hasilnya secara berulang-ulang dalam kebaikan wakaf. Pengertian kata "ada" secara alami berarti barang tersebut usianya ditentukan oleh nilai ekonominya, juga bisa berarti ada karena sesuai dengan kehendak wâqif dalam ikrar wakafnya.

Perbedaan pemaknaan hadîth wakaf di kalangan ulama tradisional lebih menekankan pemahaman dan pemaknaan hadîth wakaf secara tekstual, sedangkan ulama modern lebih menekankan pemahaman dan pemaknaan hạaith wakaf secara kontekstual. Perbedaan pendapat keduanya sangatlah variatif. Hal ini disebabkan karena horizon pendidikan mereka yang berbeda.

\section{Daftar Rujukan}

al-Munawwar, Said Agil Husain., dan Mustaqim, Abdul. Asbabul Wurud: Studi Kritis Atas Hadis Nabi, Pendekatan Sosio, Historis, Kontekstual. Yogyakarta: Pustaka Pelajar, 2001.

Bukhârî (al), Abû 'Abd Allâh b. Ismâil b. Ibrâhîm b. al-Mughîrah Bardizbah al-Ju'fî. Șahîh al-Bukhârî, Vol. 3. Beirut: Dâr al-Fikr, 1994.

Fikrî, 'Alî. al-Mu'âmalât al-Mâdiyah wa al-Adâbîyah, Vol. 2. Mesir: Muștafâ al-Bâbî al-Halabî, 1938), 307. 
Hạanâi (al), Ibrâhîm b. Mûsa b. Abî Bakr b. al-Shaykh 'Alî alTarablîshû. al-Is'âf fî̀ Aḅkâm al-Awqâf. Mesir: Maktabat 1-Kubrâ, t.th.

Ismail, M. Syuhudi. Metodologi Penelitian Hadis Nabi. Jakarta: Bulan Bintang, 2007.

Muhammad b. 'Îsa b. Sawrah b. Mûsâ b. al-Dahhậk al-Sullamî alTirmîdhî, Sunan al-Tirmîdhî, Vol. 5. Beirut: Dâr al-Fikr, 1994.

Mustaqim, Abdul. Ilmu Ma'anil Hadis: Paradigma Interkoneksi. Yogyakarta: Idea Press, 2009.

Mustaqim, Abdul. Paradigma Integrasi-Interkoneksi dalam Memahami Hadis. Yogyakarta: Teras, 2009.

Nasâ'î (al), Abû 'Abd al-Raḥmân Aḥmad b. Shu'ayb b. 'Alî b. Sinân b. Bahrr b. Dînâr. Sunan al-Nasầî, Vol. 5. Beirut: Dâr al-Kutub al'Ilmîyah, 1995.

Naysâbûrî (al), Muslim b. al-Hajajâj b. Muslim al-Qushayrî. al-Jâmi“ alSabîh, Vol. 5. Beirut: Dâr al-Fikr, 1993.

----. al-Jâmi' al-Șabîh, Vol. 5. Beirut: Dâr al-Fikr, 1993.

----. Sahîh Muslim, Vol. 2. Bandung: Dahlan, t.th.

Praja, Juhaya S. Hukum Wakaf di Indonesia. Bandung: Yayasan Piara, 1995.

Qudâmah, Ibn. al-Mughnî, Vol. 8. Mesir: Hajar, 1989.

Quzwaynî (al). Abû 'Abd Allâh Muhammad b. Yazîd b. Mâjah alRabî̀. Sunan Ibn Mâjah, Vol. 2. Kairo: Dâr al-Hạadîth, 1988.

Sâbiq, Sayyid. Fiqh al-Sunnah, Vol. 3. Mesir: Dâr al-Fath li-I'lâm al'Ilmîyah, t.th.

Sharbînî (al), Muhammad al-Khaṭ̂ib. Mughnî al-Mubtâj, Vol. 2. Mesir: Muștafâ al-Bâbî al-Halabî, 1958.

Sijistânî (al), Abû Dâwud Sulaymân b. al-Ash'ath b. Ishậq b. Bashîr alAzdî. Sunan Abî Dâwnd, Vol. 2. Beirut: Dâr al-Kutub al-'Ilmîyah, 1996.

Siwâsî (al), al-Kamâl b. Hammâm Muhammad b. 'Abd al-Wâhịd b. 'Abd al-Hạîî b. Mas'ûd. Fatḥ al-Qadîr, Vol. 5. Mesir: Mustafâ Muhammad, t.th.

Yamanî (al), Muhammad b. Ismâ'îl al-Kahlanî al-Ṣan‘ânî. Subul alSalâm, Vol. 3. Bandung: Multazam, t.th.

Zahrah, Muḥammad Abû. Mụ̂ậarât fì al-W aqf. Beirut: Dâr al-Fikr al'Arabî, 2005. 


\section{Wawancara}

Afif. Wawancara. Gresik, 12 Januari 2014.

Amin, Nasihun. Wawancara. Gresik, 5 Januari 2014.

Aziz, Abd. Wawancara. Gresik, 11 Januari 2014.

Bachruddin. Wawancara. Gresik, 25 Januari 2014.

Basyir, Muhammad. Wawancara. Gresik, 4 Januari 2014.

Bisyri, Hasan. Wawancara. Gresik, 25 Januari 2014.

Choliq, Abd. Wawancara. Gresik, 11 Januari 2014.

Farhan. Wawancara. Gresik, 4 Januari 2014.

Khoiruddin. Wawancara. Gresik, 5 Januari 2014.

Kholif. Wawancara. Gresik, 5 Januari 2014.

Manan, Kamaly. Wawancara. Gresik,12 Januari 2014.

Midhhar. Wawancara. Gresik, 19Januari 2014.

Misbach. Wawancara. Gresik, 4 Januari 2014.

Mujib, Abd. Wawancara. Gresik, 18 Januari 2014.

Rochim, Nur. Wawancara. Gresik, 26 Januari 2014.

Sobir, Moh. Wawancara. Gresik, 25 Januari 2014.

Suwanto. Wawancara. Gresik, 12 Januari 2014.

Syaiful. Wawancara. Gresik, 26 Januari 2014.

Tohir. Wawancara. Gresik, 11 Januari 2014.

Zaini, Muhammad. Wawancara. Gresik, 19 Januari 2014.

Zunaidi, Syueb. Wawancara. Gresik, 4 Januari 2014. 